UDC 304.5: 316.7

Yu. Pylypenko ${ }^{1}$, Dr. Sc. (Econ.), Prof., orcid.org/0000-0002-4772-1492,

H. Pylypenko ${ }^{1}$, Dr. Sc. (Econ.), Prof., orcid.org/0000-0003-2091-4320,

N. Lytvynenko ${ }^{1}$, Dr. Sc. (Econ.), Assoc. Prof., orcid.org/0000-0003-3797-8398,

O. Tryfonova ${ }^{1}$, Dr. Sc. (Econ.), Assoc. Prof., orcid.org/0000-0003-2283-6258,

E. Prushkivska ${ }^{2}$, Dr. Sc. (Econ.), Prof., orcid.org/0000-0002-4227-8305
DOI: 10.29202/nvngu/2019-3/21

1 - Dnipro University of Technology, Dnipro, Ukraine, e-mail: pylypenkoYI@gmail.com; annapylyp@ukr.net; nata1yt33@ukr.net; elenatriphonova@gmail.com

2 - Zaporizhzhya National Technical University, Zaporizhzhia, Ukraine, e-mail: em.prushkovskaya@gmail.com

\title{
INSTITUTIONAL COMPONENTS OF SOCIO-ECONOMIC DEVELOPMENT
}

Purpose. The identification of the main informal institutions of Ukrainian society by identifying the social and cultural values which make their core, as well as revealing of the specifics of their impact on the country's social and economic development.

Methodology. The conceptual approaches to institutional economic theory served as the methodological basis of the research. This allowed considering informal institutions of society as organizations, which have social and cultural values in its basis. They are structurally represented by valuable orientations and social and psychological orientations. The estimation of value orientations was based on Sh. Schwartz's methodology, while social, psychological orientations were discovered according to O. Potemkina's method, and they were assessed by using the weighted arithmetic mean. The comparison of valuable orientations and social and psychological orientations was carried out on the basis of comparative analysis.

Findings. It is shown that social and economic development of society depends on people's economic activities in the institutional environment, which is formed by formal and informal institutions. In order to ensure the progress of society, it is important to choose such formal institutions that do not contradict the informal norms and rules which have been established in society under the influence of culture during the historical period of development. It is demonstrated that at the heart of any social institution there are social and cultural values which describe the general strategies of human activities and acquire specific forms of manifestation due to value orientations and social and psychological orientations. The theoretical basis and methodology of evaluation of valuable orientations and social and psychological directions are presented. On the basis of the data of the European Social Survey, Charles Schwartz's indexes of valuable orientations were calculated .They were compared with the indices of social and psychological orientations obtained on the basis of empirical studies, conducted by the authors on a sample of 2,058 Ukrainians. A comparative analysis of valuable orientations and social and psychological orientations of the Ukrainians and Russians is carried out. The influence of informal institutions on the character of social and economic development of these countries is shown.

Originality. The structural organization of the informal institute is revealed as a dynamic construct, formed of social and cultural values, valuable orientations and social and psychological orientations makes the scientific novelty of current study. A combination of the research of the informal social institutions according to S. Schwartz and O. Potemkina's methods, which reveals, both, the orientation of individual actions and the way of achieving the goal in common direction, becomes a new theoretical and methodological approach.

Practical value. Scientific ideas about the dependence of society's social and economic development on the social and cultural components, which are represented by informal institutions, allow expanding the range of determinants that can be regulated in order to guide society through progress. Under such conditions, it is possible to make social transformations in accordance with the dominant values of the existing culture. On the one hand, this is an opportunity to introduce reforms more effectively, and, on the other hand, less painfully for people who have had shaped their worldview during long historical development.

Keywords: socio-economic development, informal institutions, social and cultural values, valuable orientations, social and psychological orientations

Introduction. Social and economic development of society has always been in researchers' center of attention, beginning from classical economists of the seventeenth century and ending with the representatives of modern areas of the economic theory. The researchers

(C) Pylypenko Yu., Pylypenko H., Lytvynenko N., Tryfonova O., Prushkivska E., 2019 sought to find the factors and mechanisms with the help of which countries achieve a higher level of well-being. Initially, these were ideas about the progress made by resources and technological factors. Further, factors which were not economical by their nature but had a significant impact on economic processes were included to this list. Today nobody doubts that such components as politics, ideology, law, culture, specifics of the nation's 
mentality are important components of the social and economic development of any society.

Unfortunately, the recognition of the influence of non-economic (institutional) factors on the course of economic processes did not ensure the progress of Ukrainian society at the theoretical level. Currently, we have the lowest welfare indicators in Europe, impressively uneven distribution of income, social vulnerability of a larger part of the population and high level of corruption. The question arises quite logically: why has Ukraine not entered the trajectory of progressive social and economic development despite a series of so-called progressive reforms?

It seems that such a situation is due to the politicians' concentration mainly on the formation of new more effective formal institutions and the underestimation of the impact of informal institutions on the economy. This results in inconsistencies in the institutional environment. The overwhelming majority of society's members do not recognize new formal rules, because they are exposed to inappropriate intellectual designs that motivate a person to act. This provokes an institutional conflict and slows down social and economic development. Therefore, it is important to find solutions to such a conflict and create such an institutional environment that will be able to contribute to the consistent social and economic development of society.

Literature review. The influence of informal institutions on the origin of institutional changes in society has been investigated thoroughly in economic science. The fundamental work by T. Veblen (Veblen 1899), Weber (1958), D. North (North, 1990, 2005) became the conceptual basis of regularity according to which universally accepted norms and rules of behavior, being part of culture, are passed from generation to generation through social mechanisms of imitation and suggestion, forming the basic principles of motivation of society's members and affecting the economic growth. At the same time, P. David and B. Arthur showed that informal norms, being the expressions of the traditional mental constructions of representatives of a particular culture, have a tendency to continue their existence for a very long time, and they are not subject to a considerable conscious desire for change (David, 1985; 1986) (Arthur, 1990). Therefore, any country characterized by "dependence on previous development" can experience the effect of being "stuck in a rut" which forces one state or another to move in a given direction with very limited opportunities [1]. Consequently, any institutional changes can only be effective when new formal rules are adapted to existing informal norms within the limits of permissible opportunities that are determined by social and cultural factors.

In our previous works, it was shown that social and cultural values, and generalized positive or negative values of objects, which are directed by human actions in his/her desire to meet the needs, are the basic component of any informal institution. These values acquire the quality of certain ideas and beliefs, help people to choose the right ways in achieving economic goals and determining the internal readiness to be engaged into certain activities. Due to this, values serve as the basis for the motivation of all types of human activities [2]. Since social and economic development has been the process driven directly by a person, then it is very important to understand the motives of the actions contributing to or hindering the movement of society to a better state. Therefore, if one knows what values determine the economic behavior of members of a particular society, then one can understand the very nature of social and economic development and one can consciously manage this process, adapting new formal institutions to existing values of society or gradually changing the latter in the desired direction.

Currently we have powerful analytical diagnostic instrument of social and cultural values, developed by Hofstede (1980), Inglehart (1997), Schwartz (1999) and other researchers, as well as empirical data on the dominant values of more than 80 countries of the world obtained during the implementation of international projects, in particular, the European Social Survey (ESS) and the World Values Survey (WVS). These studies have made it possible to demonstrate that culture is important and it has sometimes crucial value in ensuring the development. According to Hofstede's research, longterm oriented individualistic cultures with high masculinity, low levels of power and avoidance of uncertainty have more effective mechanisms for ensuring social welfare than countries with collectivistic cultures (Hofstede, 1980; 1994; 2001). R. Inglehart showed that in countries with dominating post-materialistic values, the GDP per capita exceeds 15 thousand dollars a year in contrast to poor countries with prevailing traditional values (Inglehart, 1997, 2000). Similar results were obtained by other scholars, who investigated the stereotypes of behavior, norms and values with the subsequent search for their connection with the macroeconomic indicators of socio-economic development [3].

Being used for country development strategies, these achievements in economics allowed taking into account the influence of people's mentality and, based on this, choosing institutions that are more effective. However, to identify the direct mechanisms of development, more in-depth research is required. The essence of the problem lies in the fact that the values describe only the general possible strategies of human activities and show nothing about how people will exactly act in certain situations. Social and cultural values are the phenomenon of social consciousness, which assesses the objects, approves or condemns them and serves as a guide in the daily activities of a man. A person reacts to the influence of the environment only after comprehending the values and changing them in their consciousness. Therefore, we must know not only what reflects the internal readiness and the people's tendency to be engaged in certain activities, and what influences their choice, but we must also know the mechanism of such choice.

The purpose of this article is to identify key informal institutions of Ukrainian society by identifying the social and cultural values that compose their basics, as well as to reveal the specifics of their influence on the country's social and economic development. 
Results. The information about people's propensity to be engaged into certain activities and their type of motivation provides us with value orientations rather than proper values, these orientations being special psychological constitutions that are a form of inclusion of social values into the mechanism of activities and behavior of the individual. They reflect a certain degree of transition of societies' values into direct activities of the subject. They reflect the readiness of a person to act in one or another way, which becomes more specific in the course of the formation of social and psychological trends, so-called unconscious psychological states of a person, based on his/her previous experience, his/her readiness for a certain type of activity under the prevailing conditions. Social and psychological trends are formed because of the emergence of a stereotype such as a generalization of the phenomenon, which transfers into a stable conviction and influences the entire system of human relations, their behavior and mental processes. Consequently, in our opinion, stereotypes of human behavior in the economic sphere are deeper determinants of the development, because they transform the economic activity of subjects into specific behavioral mechanisms contributing to it or slowing it down.

Considering the existing research on this issue, it should be noted that the discovery and assessment of behavioral stereotypes of different countries' representatives have not been widely disseminated in the crosscultural analysis. Currently we have empirical data about the nature of the values of the individual level only in that part which was obtained in the course of conducting international research according to Sh. Schwartz's (Shwartz, 1992) method. All other studies are aimed at identifying the values of the social level of consciousness. Schwartz concentrates on valuable orientations, which are, in his opinion, external to people and are manifested in the features of the stimuli and expectations that members of a particular cultural group meet. For example, the cultural value of modesty and subjugation is expressed in the stimuli and expectations that encourage the spread of conformity and the desire to "stay in the shadows". In addition, this does not contribute much to the development of entrepreneurship, innovation activity as a key factor in the development. Thus, social institutions as a product of culture, exercising pressure on the individual, determine the orientation of their specific actions and all life activity [4]. Therefore, Schwartz investigates 10 value orientations, which reflect motivational trends in terms of the basic needs of the individual, namely: security, tradition, conformity, self-direction, stimulation, hedonism, benevolence, universalism, power and achievement (Schwartz \& Ros, 1995; Schwartz \& Bardy, 1997).

It is well-known that institutions limit the field of possible behavioral alternatives, reducing uncertainty. Informal institutions are the embodiment of internal rules of behavior that are mandatory for a person, which begin to function as principles of motivation and form stereotypes through habituation. Behavioral manners reflected in stereotypes are no longer value orientations, but social and psychological orientations. By virtue of this, Sh. Schwartz's method allows us to determine the direction of action; still it does not reflect the methods of achieving them stereotypically. Therefore, to reflect the entire complex of emotional and behavioral factors of economic behavior of subjects, other approaches must be applied along with Sh. Schwartz's method.

The methodology of diagnostics of social and psychological orientations of a personality in the motivation-demand sphere, represented by O. Potemkina (Potemkina, 2001), is one of such approaches. This technique allows us to determine the degree of expression of the socio-psychological orientations of the person in both directions of the scales. The first direction allows us to find directions aimed at the value orientations of "altruism-egoism", "process-result". The second direction is the direction of "freedom-power" and "labormoney". Thus, in our opinion, by combining the definition of socio-cultural components of informal institutions in the methods developed by S.Schwartz and O. Potemkina, we can identify, firstly, the type of personality motivation, which is determined by its value orientations, and secondly, socio-psychological directions that characterize stereotypes of behavior.

Such scientific problem is solved by analyzing the comparison of Schwartz' value orientation indexes, obtained during the implementation of the European Social Survey (ESS) and the indices of social and psychological orientations of the person in the motivation and demand sphere, based on the methodology of O. Potemkina, calculated by the authors of current study, based on the results of implementation of our own research project "Economic outlook of Ukrainian society in the period of transformation changes" (state registration number 0110U001828). This project was carried out through a survey of 2,058 respondents, representing all the regions of Ukraine. The sampling consisted of $44 \%$ of men and $56 \%$ of women, approximately corresponding to the gender-age distribution of the population, and it covered people of different age, level of education, profession and confession [5]. Ukraine and Russia were chosen to demonstrate the specificity of informal institutions of different countries, which predetermine their uneven development. This choice is conditioned by the fact that the study of social and psychological orientations of a person in the motivation and demand sphere, according to the methodology of O. Potemkina, was carried out only in these two countries, while the method of Sh. Schwartz has covered the majority of European countries.

Index estimations of value orientations according to Schwartz's method were conducted using a weighted average arithmetic mean, applying a centering procedure based on the empirical data of the European Social Survey, which are publicly available on the official website of the European Social Survey and in strict accordance with the proposed ESS methodology [6]. The data of the fourth round (2008) is used in the analysis, which is connected with our own research on social and psychological trends in the motivation and demand sphere, which was conducted in 2009. The sampling comprising 1828 persons for analytical comparison was formed for 
Ukraine, and for the Russian Federation it comprised 2500 persons. Centered indexes of value orientations according to Sh.Schwartz are represented in Table 1, where the value of the index has reverse relation to the importance of this value orientation for the respondent, in relation to the average value for him of all value orientations from the list of Sh. Schwartz.

For a more visual comparison in Fig. 1 we present a graphic profile of value orientations of Ukrainians and Russians.

As follows from Table 1 and Fig. 1, there are common values for the Ukrainians and Russians, in particular, such values as security, self-direction, stimulation, benevolence, and power. This proves that the studied countries have several roughly identical motivational goals from the "Conservatism", "Openness to Changes", "Self-Enhancement", and "Self-Transcendence" categories. The security of both countries, Ukraine and Russia, is oriented towards stability, security, and harmony of society, which is an expression of the need for adaptation and predictability of the world, reducing uncertainty in accordance with value orientation. However, compared with other value orientations included into
"Conservatism" category, it shows that the Ukrainians have a higher conformance $(-0.157$ versus 0.064$)$ and less tradition $(0.087$ to -0.119$)$ compared to the Russians. The prevalence of conformity indicates the desire to limit actions and motives that can harm others or disrupt social harmony. Therefore, our compatriots are more directed at creating harmonious relations with other people and suppressing their socially destructive inclinations. However, with regard to respecting and maintaining traditions, customs, acceptance and recognition of ideas existing in society, the Ukrainians are not so conservative as the Russians and they are ready to change the dominant principles of world perception.

Being similar to the Russians, in terms of value orientations of self-direction and stimulation from the "Openness to Changes" category, the Ukrainians turned out to express less hedonism, which is the focus on sensual pleasure, enjoyment of life, and the desire for comfort $(0.742$ vs. 0.626). Benevolence, in the "Self-Transcendence" category, characterizes the inhabitants of both countries as people, who are inclined to preserve and improve the well-being of people from close surroundings. However, according to the value orientation,

Table 1

Indices of valuable orientations according to Sh. Schwartz

\begin{tabular}{|c|c|c|c|c|c|c|c|c|c|c|}
\hline & \multicolumn{3}{|c|}{ Conservatism } & \multicolumn{3}{|c|}{ Openness to Changes } & \multicolumn{2}{|c|}{ Self-Enhancement } & \multicolumn{2}{|c|}{ Self-Transcendence } \\
\hline &  & 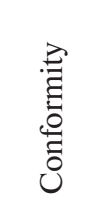 & & 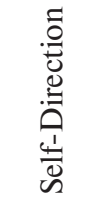 & 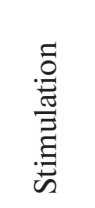 & 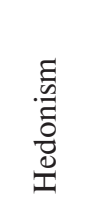 & 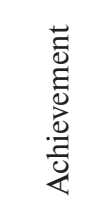 & $\begin{array}{l}\overrightarrow{0} \\
\stackrel{0}{0} \\
\stackrel{0}{2}\end{array}$ & 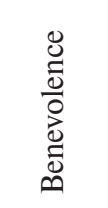 & 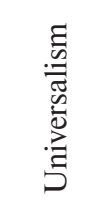 \\
\hline Ukraine & -0.737 & -0.157 & 0.087 & -0.101 & 0.825 & 0.742 & 0.295 & 0.247 & -0.411 & -0.486 \\
\hline Russia & -0.682 & 0.064 & -0.119 & -0.136 & 0.881 & 0.626 & 0.128 & 0.215 & -0.399 & -0.372 \\
\hline
\end{tabular}



Hedonism

Fig. 1. The profile of value orientations of Ukrainians and Russians 
we have certain differences in universalism. Firstly, in comparison with the Russians, the Ukrainians are more tolerant and aimed at supporting the well-being of all people ( -0.486 against -0.372$)$. Regarding the value orientations of the "Self-Enhancement" block, both the Ukrainians and Russians are primarily oriented toward power versus achievement. They are characterized by the desire to get social status and wealth, to establish prestige and control over people and resources. At the same time, the motivational goal of Ukrainians in achieving personal success and its demonstration is not so obvious, as in Russians ( 0.295 versus 0.128 for achievement value orientation).

Thus, applying Schwartz's method, we have obtained results that give us an idea of the motivational goals of the average citizen of the particular country and indicate their tendency to act accordingly under the prevailing conditions. However, value orientations are not similar to actual actions. In the second phase of our study, we will show how these inclinations turn into willingness to act stereotypically. We carry out an analytical comparison of the indices of social and psychological trends of the inhabitants of Ukraine and Russia, calculated by us on the basis of data obtained during a personal survey of respondents in these countries in accordance with the methodology by O. Potemkina. These indices were determined on the 11-point scale, where zero means the absence of this social and psychological orientation, and 10 points reflects its highest level. The average value of these indicators forms the idea of normal emotional level of personality, which corresponds to 5 points. Accordingly, the obtained values of the calculated indices for each individual direction make it possible to compare with the normal emotional level of each direction and detect a deviation from it.

Sampling for Russia was formed from empirical data, represented in the works by Russian scientists. We used the results of a survey conducted by A. Vishnyakov, that used the method of A. Potemkina, who investigated the relationship between value orientations and psychological characteristics of work motivation of employees of medical institutions [7, 8], as well as similar data obtained by T. Babayev and N. Kargin in studying the problem of effective professional activity [9]. The third component of the Russian sample was the results of a survey by L. Zakirova. The survey was conducted in order to identify priority motivational directions and value orientations for people with high and low levels of corruption orientation [10].

Since these studies were based on small sample sizes, Russian samples were combined to obtain a population that would be comparable to the number of surveyed re- spondents from Ukraine. As a result, we received a sample out of 2500 people. These results, in fact necessitated the selection of data from the European Social Survey in order to analyze S. Schwartz's indicators for a sample of that number.

Accordingly, indices for the Russian sample were calculated with the help of a weighted arithmetic average, where the indicator was borrowed from the particular study, while the number of people in the corresponding survey served as the frequency. The sample for Ukraine was formed out of 1828 people, who participated in our study of social and psychological trends in the motivation and demand sphere. The results of calculations of indices of social and psychological orientations for Ukrainians and Russians are presented in Table 2 .

In turn, Fig. 2 represents a graphic profile of the socio-psychological trends of Ukrainians and Russians.

Comparing Ukraine and Russia in social and psychological orientations in the motivation and demand sphere, we conclude that there are almost complete coincidence of indices of such trends as altruism, freedom, and labor in these countries. In addition, our compatriots and our neighbors will act more in favor of others than themselves under certain conditions. In addition, they show willingness to sacrifice for the sake of collective social goals. At the same time, freedom becomes important for them as a desire for autonomy and independence. It is combined with the psychological inclinations of people to the sense of importance of not just engagement in a certain activity, but actually having a job, labor activity (labor orientation).

Some notions that distinguish the surveyed countries are the following: focus on egoism, process, result, and money. According to the data of Table 2, the Ukrainians are more egocentric than the Russians (3.79 vs. 3.49), and therefore, they are more likely to receive cash remuneration for their work (3.35 vs. 3.10). Regarding the working activity, the Ukrainians are people with a predominant focus on the labor process than on its outcome (5.96 against 5.49 on the process and 5.86 against 6.37 on the result). This directly indicates a greater orientation of the Ukrainian population at the process of work itself, where creativity, disclosure of their own potentials, self-actualization become important. For such people, the result of work is not very important. It is rather a desirable consequence than the main goal. In other words, the average Ukrainian will not strive to achieve the result at any price, but rather focus on satisfaction with the process of work itself. At the same time, The Ukrainians are less directed at power than the Russians (3.5 vs. 3.95), which is reflected in far more mod-

Table 2

Level indices of the social and psychological orientations of the personality in the motivational and demand sphere by O. Potemkina methodology [7-10]

\begin{tabular}{|c|c|c|c|c|c|c|c|c|}
\hline Indices & Freedom & Power & Labor & Money & Process & Result & Altruism & Egoism \\
\hline Ukraine & 6.32 & 3.5 & 5.07 & 3.35 & 5.96 & 5.86 & 5.74 & 3.79 \\
\hline Russia 1 & 6.16 & 3.95 & 5.21 & 3.10 & 5.49 & 6.37 & 5.59 & 3.49 \\
\hline
\end{tabular}




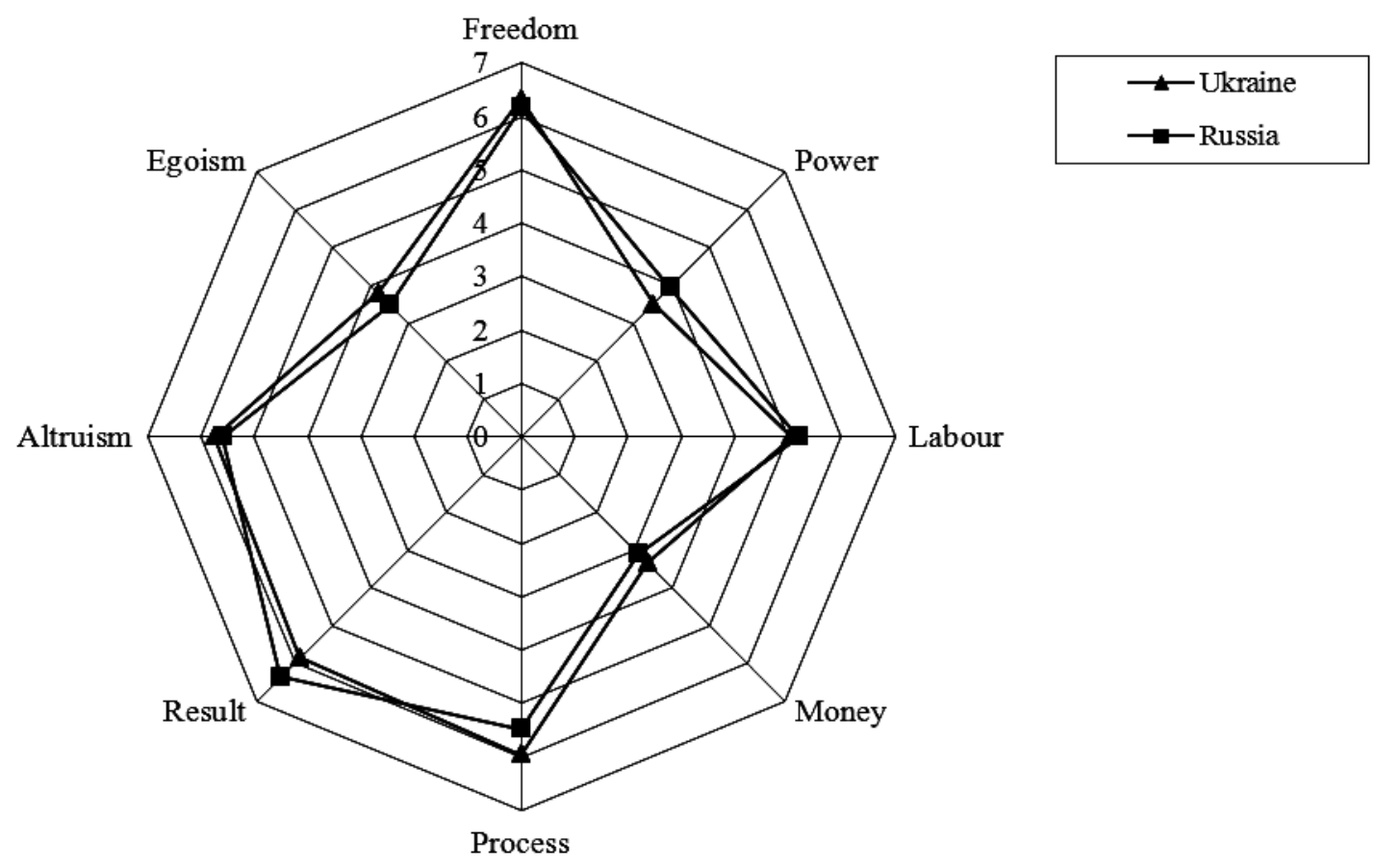

Fig. 2. The profile of socio-psychological orientations in the motivation and demand sphere of Ukrainians and Russians

erate strive to control and influence other people and societies.

Characteristics of the indices of social and psychological trends allow outlining the main institutional components of social and economic development. Under the conditions prevailing in Ukraine, its informal institutions determine a more liberal path of development than it is possible in Russia. Freedom coupled with moderate egoism and an orientation towards money, the desire to succeed at the expense of labor force creates the basis for the development of market forms in the economic operation. However, the dominance of altruism, the greater focus on the process rather than the result of labor combined with the aspirations of the power, require active state intervention in market processes and the control of civil society over the actions of the state.

Conclusions. Applying the two methods by Sh. Schwarz and O. Potemkina for the analysis of the informal institutions, we were able to obtain the characteristics of the institutional environment of the countries at two epistemological levels: in terms of value orientations determining the type of motivation; and in terms of social and psychological orientations determining specific behavioral mechanisms. By using Sh. Schwartz's method for Ukraine, we obtain clear motivation of the population (the highest values of the indices) to achieve safety, harmony and stability in society, relations with other people and oneself (safety).

The combination of security with conformity shows the desire for order, stability, and social harmony. In accordance with these types of motivation, there is also universalism, implying understanding, tolerance, protection of the welfare of others, which in combination with high benevolence, promotes satisfaction of the needs related to its existence in the external world, the abandonment of selfish interests. In combination with significant self-direction, it activates internal motivation for creativity, aspiration for novelty and change. Therefore, according to types of motivation, we have an institutional environment that cannot stimulate dramatic changes in society; it rather tends to develop through evolutionary changes.

According to social and psychological orientations, the analysis of the existing institutional environment allows us to understand that in principle, these evolutionary changes can occur due to market mechanisms, given the certain expressiveness of egoism, the simultaneous orientation of both money and labor, orientation at both the process (5.96) and the result (5.86) of labor activity. However, the path of liberal reforms is not entirely acceptable to Ukraine. The domination of altruism over egoism, high indicators of power-orientation of population does not allow defining all potencies of the value orientation of the individual to freedom and the internal motivation of self-direction. Therefore, modernization of Ukrainian society should be based on the combination of state and market mechanisms of influencing the development taking into account the specifics of institutional environment of the country.

Therefore, knowing the dominant types of motivation in society, we can only predict possible trajectory of development. The direct mechanism of its implementation reproduces the social and psychological orientations, which demonstrate solid mental constructions that motivate people to take certain actions. Therefore, the main task for the state, while implementing any social and economic reforms, is to find the exact levers of influencing the stereotypes of behavior of business entities to direct their activities in the desired direction. Under such conditions there is contradiction eliminated between formal institutions, implemented into the soci- 
ety during the modernization, and those informal rules which historically develop in social and cultural environment. Moreover, taking into account cultural values practiced by representatives of a certain culture when constructing new social institutions makes it possible to carry out transformation reforms with considerably less losses for both society and individuals.

\section{Reference.}

1. Nort, D. (2005). Understanding the Process of Economic Change. Prinston University Press. Retrieved from http://assets.press.princeton.edu/chapters/s7943.pdf.

2. Pylypenko, H. (2017). Socio-cultural factors of economic development. Dnipro: NMU.

3. Stepanenko, S.V. (2018). The Economic Values of Ukrainian Society: According to the World Values Survey. Biznes Inform, 9, 8-12.

4. Schwartz, S. H. (2011). Values: Individual and cultural. In F. J. R. van de Vijver A. Chasiotis, \& S. M. Breugelmans, (Eds.), Fundamental questions in cross-cultural psychology (pp. 463-493). Cambridge: Cambridge University Press.

5. Prushkivska, E.V., Pylypenko, H.M., \& Lytvynenko, N. I. (2013). Socio-cultural Aspects of Economic Consciousness of Ukrainians. Ekonomichniy Visnyk Natsionalnoho Hirnychoho Universytetu, 1(41), 34-45.

6. The European Social Survey: European Social Research website (n.d.) Retrieved from https://www.europeansocialsurvey.org.

7. Vishnyakov, A. I. (2016). Psychological features of labor motivation and value orientations of employees of organizations: the age aspect]. Sovremennyie problemy nauki i tehniki, 3, 299-299.

8. Vishnyakov, A. I., \& Abdrakhmanova, G.A. (2015). Psychological features of labor motivation and value orientations of employees of public and private medical institutions. Sovremennyie problemy nauki i tehniki, 1, 1589-1589.

9. Babaeva, T. M., \& Kargin, N. V. (2015). Comparative Analysis of the Motivational Sphere of People at Different Stages of Career Development. Vestnik RUDN, Pedagogy and Psychology series, 3, 39-44.

10. Zakirova, L. M. (2016). Features of the motivational and value sphere of a corrupt individual. Sotsial'no-ekonomicheskiye $i$ tekhnicheskiye sistemy: issledovaniye, proyektirovaniye, optimizatsiya, 3, 49-55.

\section{Інституціональні складові соціально- економічного розвитку}

\begin{abstract}
Ю. І. Пилипенко ${ }^{1}$, Г. М. Пилипенко ${ }^{1}$, Н. І. Литвиненко ${ }^{1}$, О. В. Трифонова ${ }^{1}$, Е. В. Прушківська ${ }^{2}$

1 - Національний технічний університет „Дніпровська політехніка“, м. Дніпро, Україна, e-mail: pylypenkoYI@ gmail.com; annapylyp@ukr.net; natalyt33@ukr.net; elenatriphonova@gmail.com

2 - Запорізький національний технічний університет, м. Запоріжжя, Україна, e-mail: em.prushkovskaya@gmail.com
\end{abstract}

Мета. Визначення ключових неформальних інститутів українського суспільства через виявлення соціокультурних цінностей, що знаходяться в їх основі, а також розкриття специфіки їх впливу на соціально-економічний розвиток країни.

Методика. Методологічною основою дослідження послугували концептуальні підходи інституціональної економічної теорії, що дозволило розглядати неформальні інститути суспільства як утворення, які мають у своїй основі соціокультурні цінності, структурно представлені ціннісними орієнтаціями й соціально-психологічними спрямуваннями. Оцінка ціннісних орієнтацій базувалась на методиці Ш. Шварца, а соціально-психологічні спрямування були виявлені на основі методики О. Потьомкіної та оцінені за допомогою зваженої середньої арифметичної. Порівняння ціннісних орієнтацій і соціально-психологічних спрямувань здійснювалося на основі компаративного аналізу.

Результати. Показано, що соціально-економічний розвиток суспільства є залежним від інституціонального середовища економічної діяльності людей, яке формується із формальних і неформальних інститутів. Для забезпечення поступального руху суспільства важливо обирати такі формальні інститути, які би не суперечили неформальним нормам і правилам, що встановилися в суспільстві протягом історичного періоду розвитку під впливом культури. Продемонстровано, що в основі будь-якого інституту суспільства знаходяться соціокультурні цінності, які описують загальні стратегії діяльності людей і набувають конкретних форм прояву через ціннісні орієнтації та соціально-психологічні спрямування. Представлені теоретичне підгрунтя та методологія оцінки ціннісних орієнтацій і соціальнопсихологічних спрямувань. На основі даних European Social Survey розраховані індекси ціннісних орієнтацій Ш. Шварца, що були співставлені з індексами соціально-психологічних спрямувань, отриманих на основі даних емпіричних досліджень, проведених авторами на вибірці 2058 жителів України. Здійснено компаративний аналіз ціннісних орієнтацій і соціально-психологічних спрямувань жителів України та РФ, показано вплив неформальних інститутів на характер соціально-економічного розвитку цих країн.

Наукова новизна. Розкриття структурної організації неформального інституту як динамічного конструкту, сформованого із соціокультурних цінностей, ціннісних орієнтацій і соціально-психологічних спрямувань. Новим теоретико-методологічним підходом є поєднання в дослідженні неформальних інститутів суспільства методик Ш. Шварца та О.Потьомкіної, що дозволяє виявити як спрямованість індивідуальних дій, так і спосіб досягнення мети стереотипним чином.

Практична значимість. Наукові уявлення щодо залежності соціально-економічного розвитку суспільства від соціокультурних складових, представлених неформальними інститутами, дозволяють розширити коло детермінант, на які можна здійснювати регулюючий вплив з метою спрямування суспільства шляхом прогресу. За таких умов від- 
кривається можливість здійснювати суспільні трансформації у відповідності до домінуючих цінностей пануючої культури, що робить реформи, 3 одного боку, більш ефективними, а з іншого менш болісними для людей, які формували свою свідомість протягом тривалого історичного розвитку.

Ключові слова: соціально-економічний розвиток, неформальні інститути, соціокультурні цінності, ціннісні орієнтації, соціально-психологічні спрямування

\section{Институциональные составляющие социально-экономического развития}

Ю. И. Пилипенко ${ }^{1}$, А. Н. Пилипенко ${ }^{1}$, Н. И. Литвиненко ${ }^{1}$, Е.В.Трифонова ${ }^{1}$, Э. В. Прушковская ${ }^{2}$

1 - Национальный технический университет „Днепровская политехника“, г. Днепр, Украина, e-mail: pylypenkoYI@gmail.com; annapylyp@ukr.net; natalyt33@ ukr.net; elenatriphonova@gmail.com

2 - Запорожский национальный технический университет, г. Запорожье, Украина, e-mail: em.prushkovskaya@ gmail.com

Цель. Определение ключевых неформальных институтов украинского общества через выявление социокультурных ценностей, находящихся в их основе, а также раскрытие специфики их влияния на социально-экономическое развитие страны.

Методика. Методологической основой исследования послужили концептуальные подходы институциональной экономической теории, что позволило рассматривать неформальные институты общества как образования, имеющие в своей основе социокультурные ценности, структурно представленные ценностными ориентациями и социальнопсихологическими установками. Оценка ценностных ориентаций основана на методике Ш. Шварца, а социально-психологические установки были обнаружены на основе методики А. Потемкиной и оценены с помощью взвешенной средней арифметической. Сравнение ценностных ориентаций и социально-психологических устремлений осуществлялось на основе компаративного анализа.

Результаты. Показано, что социально-экономическое развитие общества является зависимым от институциональной среды экономической деятельности людей, которая формируется из формальных и неформальных институтов. Для обеспечения поступательного движения общества важно выбирать такие формальные институты, которые бы не противоречили неформальным нормам и правилам, установившимся в обществе в течение исторического периода развития под влиянием культуры. Продемонстрировано, что в основе любого института общества находятся социокультурные ценности, описывающие общие стратегии деятельности людей и приобретающие конкретные формы проявления через ценностные ориентации и социально-психологические установки. Представлены теоретические основы и методология оценки ценностных ориентаций и социально-психологических установок. На основе данных European Social Survey рассчитаны индексы ценностных ориентаций Ш. Шварца, которые были сопоставлены с индексами социально-психологических установок, полученных на основе данных эмпирических исследований, проведенных авторами на выборке 2058 жителей Украины. Осуществлен компаративный анализ ценностных ориентаций и социально-психологических установок жителей Украины и РФ, показано влияние неформальных институтов на характер социально-экономического развития этих стран.

Научная новизна. Раскрытие структурной организации неформального института как динамического конструкта, сформированного из социокультурных ценностей, ценностных ориентаций и социально-психологических установок. Новым теоретико-методологическим подходом является сочетание в исследовании неформальных институтов общества методик Ш.Шварца и О.Потемкиной, что позволяет выявить как направленность индивидуальных действий, так и способ достижения цели стереотипным образом.

Практическая значимость. Научные представления о зависимости социально-экономического развития общества от социокультурных составляющих, представленных неформальными институтами, позволяют расширить круг детерминант, на которые можно осуществлять регулирующее воздействие с целью направления общества по пути прогресса. При таких условиях открывается возможность осуществлять общественные трансформации в соответствии с доминирующими ценностями господствующей культуры, что делает реформы, с одной стороны, более эффективными, а с другой - менее болезненными для людей, формировавших свое сознание в течение длительного исторического развития.

Ключевые слова: социально-экономическое развитие, неформальные институты, социокультурные ценности, ценностные ориентации, социально-психологические установки

Рекомендовано до публікації докт. екон. наук В. Я. Швецем. Дата надходження рукопису 17.01.18. 